\title{
Alternatives to the use of antibiotics for laying hens in growing phase
}

\author{
S.M.C. Tfaile", J.E. de Moraes ${ }^{1}$, F.E.L. Budiño', D.F. Soares ${ }^{1}$, N.Y. Sitanaka ${ }^{1}$, K.M.R. Duarte', \\ S.K. Kakimoto ${ }^{2}$, T.L. Reis ${ }^{3 \#}$, L. Amoroso ${ }^{4}$ \& C.C. Pizzolante ${ }^{1}$ \\ ${ }^{1}$ Animal Science Institute, São Paulo Agribusiness Technology Agency (APTA), Nova Odessa, São Paulo, Brazil \\ ${ }^{2}$ Veterinarian, Kakimoto Poultry Farm, Bastos, São Paulo, Brazil \\ ${ }^{3}$ Federal Rural University of Rio de Janeiro, Campos dos Goytacazes, Rio de Janeiro, Brazil \\ ${ }^{4}$ Department of Animal Morphology and Physiology, São Paulo State University, Jaboticabal, São Paulo, Brazil
}

(Submitted 23 January 2020; Accepted 11 June 2020; First published online 8 September 2020)

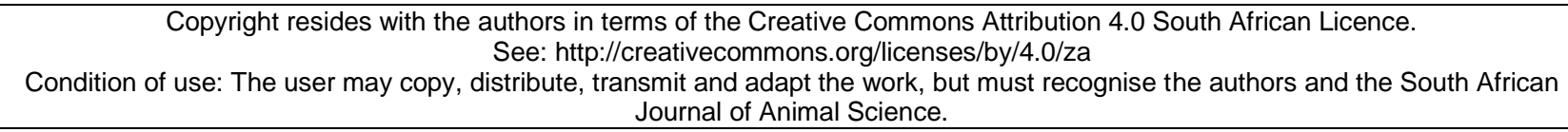

\begin{abstract}
This study evaluated the performance, immune response to vaccination, digestive organs, intestinal histomorphometry, and microbiological development in the diet and litter of Isa Brown strains at growing receiving phase alternative additives in the place of antibiotics. Four treatments were arrayed in a completely randomized design: T1) Basal diet without antibiotics, T2) Basal diet with antibiotics, T3) Basal diet with probiotics, and T4) Basal diet without antibiotics and water modified by a photoelectron generator. There were six replications of eight birds each and thus a total of 192 birds. Performance was evaluated for eight weeks and during this period blood samples were collected at 9,12 and 15 weeks of age for serological evaluation. At the end of the experimental period, 24 birds were euthanized, collecting the intestinal tract and later performing histomorphometry. Microbiological analyses were performed in the experimental diets and in the material of the litter of the boxes. The results obtained were analyzed by analysis of variance and the contrast between treatment means when significant by Tukey's test. The results indicate that the replacement of antibiotics with T3 or T4 did not interfere negatively $(P>0.05)$ in the performance of the birds, immunological response, viscera analyses and intestinal histomorphometry. In addition, use of T3 and T4 might lead to more rapid decomposition of excreta and reduce antibiotic residue in the soil when the litter is used in crop production.
\end{abstract}

Keywords: dileka, Gallus domesticus, histomorphometry, laying hens, probiotics, serum biochemistry, water \#Corresponding author: tulioreis@hotmail.com

\section{Introduction}

In poultry production, it is almost impossible to achieve high productivity and keep costs low without using feed additives (Otutumi et al., 2008). Performance-enhancing feed additives play a role in ensuring the integrity and development of the intestinal mucosa and consequently improving flock performance (Lemos et al., 2016).

Antibiotics are widely used in laying poultry production as prophylactic agents and in the treatment of pathologies, although few drugs have been formulated for laying hens. However, several drugs have been approved for use in other classes of poultry (Borsoi \& Palermo Neto, 2015). Antibiotics are metabolites from fungi, yeasts, and bacteria (Menten, 2001) that enhance performance by protecting the intestinal lumen against pathogenic microbiota (Soares, 1996) and eliminate specific pathogenic organisms (Gadde et al., 2017). The dietary provision of antibiotics has been controversial, allowing for high population densities, which may increase farm profitability and productivity by improving the growth rate from $4 \%$ to $8 \%$ and feed conversion from $2 \%$ to $5 \%$ (Ajuwon, 2015), but affects welfare negatively (Broom \& Johnson, 1993). Improper manipulation of pathogenic microbiota through performance-enhancing drugs can induce imbalances in the intestinal microbiome and trigger enteric processes owing to undesirable interactions with other pathogens (NRC, 2004). Additionally, the administration of antibiotics at prophylactic doses may generate microorganisms that are resistant to them and result in the loss of therapeutic viability, although they are necessary for treating infected animals and humans. 
Unquestionably, the short-term cost-benefit ratio supports the use of antibiotics as feed additives. In 2006, the European Union (EU) prohibited the use of antibiotics to enhance production (Lemos et al., 2016; Belal et al., 2018; Mashayekhi et al., 2018). Because of popular pressure, researchers have sought to identify viable alternatives (Albuquerque, 2005). The formulation of rations without additives that would help to modulate the enteric microbiome would reduce animal performance and increase risks to animal health. Thus, antibiotics should be replaced with additives that act similarly (Reis \& Vieites, 2019). Antibiotic substitution studies are important to maintain beneficial effects of feed additives and eliminate undesirable ones such as bacterial resistance (Vijayasteltar et al., 2016; Al-Shammari et al., 2017). The market for such products has increased and their use has become more widespread in livestock production, because they leave no residues (Brenes \& Roura, 2010) and do not cause bacterial resistance. Probiotics can be used as replacements for antibiotics to improve performance and animal immune response, and are recognized as safe by the consumer (Brenes \& Roura, 2010).

Probiotic products are single or mixed cultures of microorganisms that produce beneficial effects in the host by increasing the properties of the native microbiota when administered to animals or humans (Fuller, 1989; Havenaar et al., 1992). Their main form of action is through competitive exclusion in which beneficial microbiota adhere in greater quantity to binding sites in the gut and prevent them from being occupied by pathogenic bacteria. This increased concentration of beneficial microbiota also has an advantage in competing with pathogens for nutrients (Corcionivoschi et al., 2010). In addition, organic acids and other bactericidal substances produced by the beneficial microbiota inhibit the multiplication of pathogenic bacteria such as Salmonella sp. and Escherichia. coli (Hinton et al., 2000). Probiotic microorganisms can also stimulate the immune system through macrophage activation, T-cell proliferation, and interferon production (Leedle, 2000). They are also responsible for increased mucin secretion in the intestine, which protects the intestinal mucosa against the adhesion of pathogens, preventing them from initiating an inflammatory process in the intestine (Oliveira-Sequeira et al., 2008). Thus, these pathogenic organisms become free in the intestinal lumen and are excreted by the animal. The classic signs of an ongoing immune response in the gut include increased infiltration of leukocytes in the lamina propria and changes in the gut structure such as villous atrophy and crypt enterocyte hyperplasia (Smith \& Beal, 2008). Probiotics also stimulate cytokine production, increase the release of immunoglobulin secretion, produce bacteriocins, and increase the junction between intestinal mucosa cells to prevent intracellular bacterial invasion (Fonseca, 2010).

Water is an important medium for the propagation of pathogens. The most widely used chemical disinfectant for water treatment is chlorine. However, despite its bactericidal efficiency, potential toxicity of by-products of chlorination make the process less attractive (Prestes, 2007). Therefore, other forms of water decontamination that avoid the formation of residues could be advantageous. The treatment of water with a photoelectron generator is one of these processes. A photoelectron generator is built as a condenser (Dileka, 2019). The core material is positioned inside a tube and produces multiple clockwise and anticlockwise vortexes as water passes through it. With water pressure, millions of micro-bubbles and multiple vortexes are produced simultaneously. The static electric current causes separation of chemicals in the water and gives it a bactericidal effect that is effective against Legionella and $E$. coli in particular.

Therefore, the objective of the study was to compare a ration supplemented with an antibiotic (T1), a ration supplemented with a probiotic (T3), and water that had been treated with a photoelectron generator (T4) for effects on the performance, vaccine efficacy, measurements of the organs of the gastrointestinal tract and histomorphometry of the small intestine of semi-heavy layers during the growing phase of their development. The second objective was to determine the effects of these treatments on microbiological development in the litter relative to the basal diet.

\section{Material and Methods}

The protocols for this experiment were approved by the Ethics Committee of São Paulo Agribusiness Technology Agency (protocol number 275/19). As an adaptation phase, 192 layers of the ISA Brown line were housed from the first day of life in an aviary measuring $6.0 \times 18.0 \mathrm{~m}$, with $0.50 \mathrm{~m}$ high walls and $1.50 \mathrm{~m}$ galvanized wire screens. The building was equipped with external and internal curtains, with closed sidewalls and Marseille tile roof. It contained 24 boxes on the floor and utility corridor. Boxes $(1.0 \times 2.0 \mathrm{~m})$ were screened and equipped with pendular feeders and nipple drinkers. They had $5 \mathrm{~cm}$ wood shavings on the floor during the experiment to give greater comfort to the animals. The pullets were kept warm during the first 15 days and given water and feed ad libitum throughout the experiment until they were six weeks old. The birds were immunized against Marek disease and coccidiosis at one day old, Newcastle disease and bronchitis at 7,28, and 56 days old), Gumboro at 7, 14, 21, and 28 days old, coryza and mycoplasma at 35 days old, bouba and encephalomyelitis at 42 days old, pneumovirus at 14 and 63 days old, E. coli at 63 days old, and Salmonella at 7 and 56 days old. 
A completely randomized design (DIC) and four treatments were arrayed in a completely randomized design: T1) Basal diet without antibiotics, T2) Basal diet with antibiotics, T3) Basal diet with probiotics, and T4) Basal diet without antibiotics and water modified by a photoelectron generator. The experimental diets were isoenergetic and isonitrogenous and formulated on corn and soybean meal with nutritional composition based on tables from Rostagno et al. (2011) (Table 1).

Table 1 Composition of the experimental diets fed to Isa Brown pullets from 7 to 15 weeks old

\begin{tabular}{lcc}
\hline \multirow{2}{*}{ Ingredients, \% } & \multicolumn{2}{c}{ Growth phase } \\
\hline & 7 to 11 weeks old & 12 to 15 weeks old \\
\hline Corn grain & 61.9 & 57.7 \\
Soybean meal (46\% crude protein) & 26.1 & 18.6 \\
Wheat meal & 8.7 & 20.8 \\
Limestone 38\% Ca & 1.1 & 1.2 \\
Dicalcium phosphate & 1.2 & 0.9 \\
Vitamin and mineral supplement ${ }^{1}$ & 0.4 & 0.4 \\
Salt & 0.3 & 0.3 \\
DL-Methionine 99\% & 0.2 & 0.1 \\
L-Lysine 78\% & 0.1 & 0.003 \\
Phytase 10000 (Poedeira) & 0.003 &
\end{tabular}

Calculated nutritional composition

Metabolizable energy, $\mathrm{kcal} / \mathrm{kg}$

Crude protein, \%

Ether extract, \%

Crude fibre, \%

Calcium, \%

Total phosphorus, \%

Available phosphorus, \%

Sodium, \%

Chlorine, \%

Total lysine, \%

Digestible lysine, \%

Total methionine, \%

Digestible methionine, \%

Methionine+total cystine, \%

Methionine+digestible cystine, \%

Total threonine, \%

Digestible threonine, \%

Total tryptophan, (\%

Digestible tryptophan, \%

Total arginine, \%

Total isoleucine, \%

Total valine, $\%$

Linoleic acid, \% 
folic acid: $175 \mathrm{mg}$, Butylated hydroxytoluene: $20 \mathrm{mg}$, phytase: 50,000 FTU, pethionine: $173.25 \mathrm{~g}$, choline: $32.56 \mathrm{~g}$, copper: $2,5 \mathrm{mg}$, iron: $12.5 \mathrm{~g}$; iodine: $300 \mathrm{mg}$, manganese: $20 \mathrm{~g}$, selenium: $50 \mathrm{mg}$, zinc: $15.0 \mathrm{~g}$ per $\mathrm{kg}$ of supplement

The performance of the live birds was evaluated over eight weeks. The birds received water and feed ad libitum. The orts were removed from each box and weighed every seven days to estimate the average feed intake per bird. Feed intake was the difference between the weight of feed provided and the weight of the orts. The birds were also weighed every seven days. Data included the average initial and final bodyweights (g), average feed intake, average daily feed intake, accumulated feed intake, average bodyweight gain, average daily bodyweight gain, and feed conversion. There was no mortality of the birds.

At the end of experiment, a bird of average weight was chosen from each replicate, six per treatment, and removed. These 24 birds were weighed again and euthanized, according to the criteria for Isa Brown (CONCEA, 2013). The carcasses were dissected to obtain the glands (liver and pancreas) and organs (intestine) of interest. The lengths and weights of the duodenum, jejunum, ileum, cecum and colon-rectum were recorded.

Blood was collected at night for serological evaluation of titers against Newcastle disease virus and avian bronchitis virus. Prior to collection, the birds were fasted for one hour. The samples were collected by venipuncture of the right brachial vein with $3 \mathrm{ml}$ blood being drawn into a vacuum tube without an anticoagulant. Samples were collected from one bird per replicate at 9, 12, and 15 weeks old. Titers were determined by enzyme-linked immunosorbent assay. The results were measured as a ratio of optical densities with cut-off values of 0.35 and 0.20 for Newcastle disease virus and avian bronchitis virus, respectively.

The histomorphometry of the small intestine was performed by separating $1.0 \mathrm{~cm}$ samples of the middle portion of each segment (duodenum, jejunum and ileum). The samples were then washed in distilled water, extended by the serous tunic, and opened and fixed with $10 \%$ formaldehyde. Subsequently, the material was dehydrated in an increasing series of alcohol from $70 \%$ to $100 \%$. The samples were diaphanized in benzol, processed and embedded in histological resin. Five semi-serial histological sections of seven micrometres thick were made and stained according to the haematoxylin and eosin technique (Tolosa et al., 2003). The stained slides were viewed under a light microscope at the Department of Animal Morphology and Physiology, Unesp of Jaboticabal. The images were captured on the Olympus DP 11 microcamera and stored on a USB stick. Morphometric analysis was performed with Image Pro Plus software (Media Cybernetics ${ }^{\circledR}$, Brazil, version 6.0). The lengths of six villi and the depths of six well-oriented crypts were measured on each side of the cuts in the sequence in which they lay in the small intestine and their lengths $(\mu \mathrm{m})$ were measured in a straight line. The measurements at the height of the villi were taken from the upper base of the crypt to the apex of the villi. The crypts were measured between the villi from the lower base to the upper base of the crypt (Fukayama et al., 2005; Gava et al., 2015).

Microbiological analyses of the diets were performed with samples of approximately $500 \mathrm{~g}$, which were collected aseptically in sterile flasks immediately after making the diets. Three replicate samples per treatment were refrigerated at $4{ }^{\circ} \mathrm{C}$ to $12{ }^{\circ} \mathrm{C}$ in closed in plastic bowls until they were analysed. The total microorganism count was determined according to the methodology recommended by APHA (2001). Briefly, $1 \mathrm{~g}$ of each sample was diluted with $50 \mathrm{~mL}$ physiological saline. Then 10 serial dilutions (base 10) were made and seeded in PDA (potato $200 \mathrm{~g}$, dextrose $20 \mathrm{~g}$, agar $20 \mathrm{~g}$, and water $01 \mathrm{~L}$ ). To make the PDA, potatoes were minced and boiled in $500 \mathrm{~mL}$ of water until tender. The material was strained and the other reagents and distilled water were added to bring the volume to $1 \mathrm{~L}$, which was then autoclaved for 20 minutes at $1 \mathrm{~atm}$. The medium was poured into $9 \times 15 \mathrm{~mm}$ Petri dishes. After incubation for 24 hours at 35 ${ }^{\circ} \mathrm{C}$, colony-forming units (CFU/g) in each dish were counted.

Six replicate samples of the poultry litter were collected from each treatment, avoiding areas around the feeders and drinkers. They were processed in a manner similar to that of Singh and Walker (2006). After being homogenized and refrigerated, the litter samples were handled in the same way as the feed samples.

The data were analysed by one-way analysis of variance. When the treatment effects were significant, their means were compared using Tukey's test at a $5 \%$ level of probability. All analyses were performed with SISVAR software (Ferreira, 2011).

\section{Results and Discussion}

Temperature and humidity in the facility where the birds were housed were $19{ }^{\circ} \mathrm{C}$ and $78 \%$, respectively. This environment can be classified as comfortable for the birds and believed not to influence the results that are presented in Table 2. 
Table 2 Performance of 7- to 14-week-old Isa Brown pullets at growing phase that received alternatives to antibiotics

\begin{tabular}{|c|c|c|c|c|c|}
\hline & \multicolumn{4}{|c|}{ Treatments } & \multirow[b]{2}{*}{ SE } \\
\hline & T1 & $\mathrm{T} 2$ & T3 & $\mathrm{T} 4$ & \\
\hline Initial weight (g) & 521.2 & 519.2 & 520.9 & 520.6 & 0.44 \\
\hline Final weight $(g)$ & 1447.7 & 1435.9 & 1414.1 & 1428.2 & 8.52 \\
\hline Feed intake (g) & 485.2 & 475.7 & 486.4 & 455.4 & 7.17 \\
\hline Daily average feed intake & 76.3 & 74.1 & 76.3 & 70.1 & 1.46 \\
\hline Bodyweight gain (g) & 116.1 & 114.4 & 111.6 & 113.4 & 0.94 \\
\hline Average daily gain (g/day) & 17.9 & 17.4 & 17.0 & 17.4 & 0.18 \\
\hline Feed conversion ${ }^{1}$ & 5.1 & 5.0 & 5.3 & 5.1 & 0.06 \\
\hline Viability (\%) & 100.0 & 100.0 & 100.0 & 100.0 & - \\
\hline
\end{tabular}

T1: Basal diet without antibiotics, T2: Basal diet with antibiotics, T3: Basal diet with probiotics, and T4: Basal diet without antibiotics and water modified by a photoelectron generator

The immune response to Newcastle disease virus (Figure 1) was above the cut-off limit of optical densities for positive and negative results (cut-off $=0.35$ ) for all treatments. There was no significant difference between the treatments, suggesting that the birds were adequately protected. These results disagree with those of Zhang et al. (2012), who found that laying hens supplemented with probiotics for 15 days had a higher antibody titer against Newcastle virus than unsupplemented control hens. In addition, Zhang et al. (2012) indicated that blends of probiotics had a greater beneficial effect on immune response than single strains.

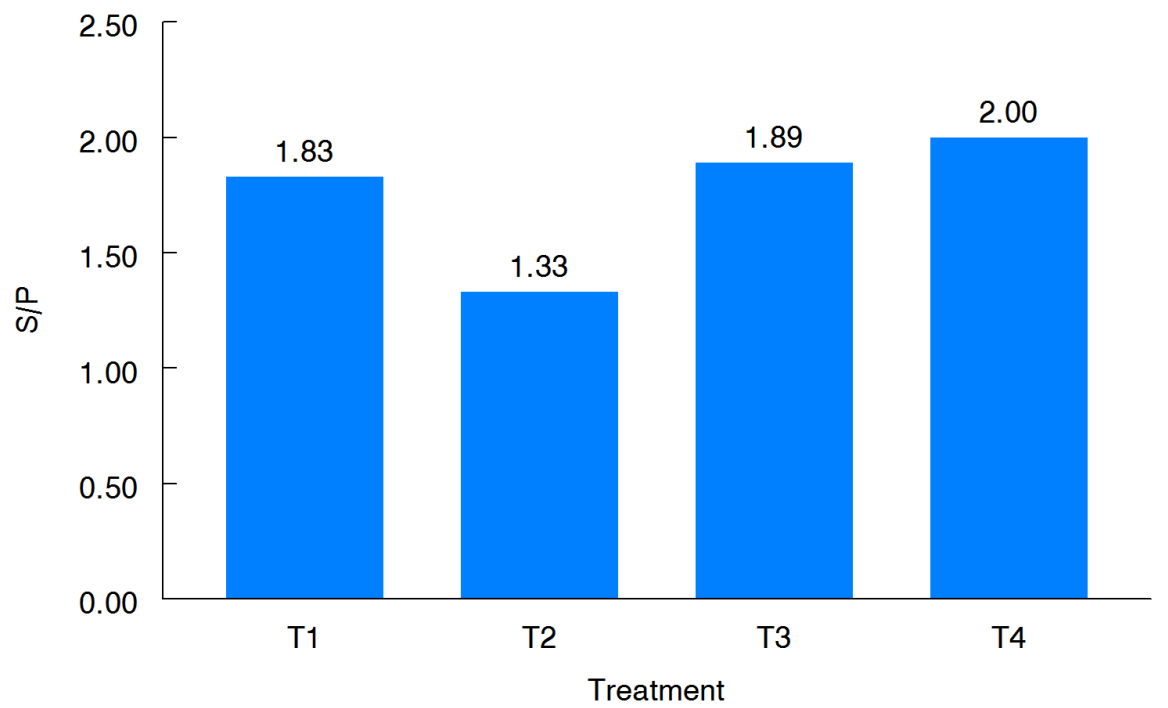

Figure 1 Treatment effects on immunologic response by Isa Brown pullets to Newcastle disease virus as measured by the optical density ratio S/P

T1: Basal diet without antibiotics, T2: Basal diet with antibiotics, T3: Basal diet with probiotics, and T4: Basal diet without antibiotics and water modified by a photoelectron generator

The immune response to infectious bronchitis disease virus was less satisfactory than for Newcastle disease virus (Figure 2). Only T2 produced an immunological response that was above the cut-off limit (cutoff $\mathrm{S} / \mathrm{P}=0.20$ ). $\mathrm{T} 1, \mathrm{~T} 3$, and T4 treatments did not provide satisfactory protection against the disease. In spite 
of the level of protection being below the minimum threshold, there was no illness of the birds in this experiment.

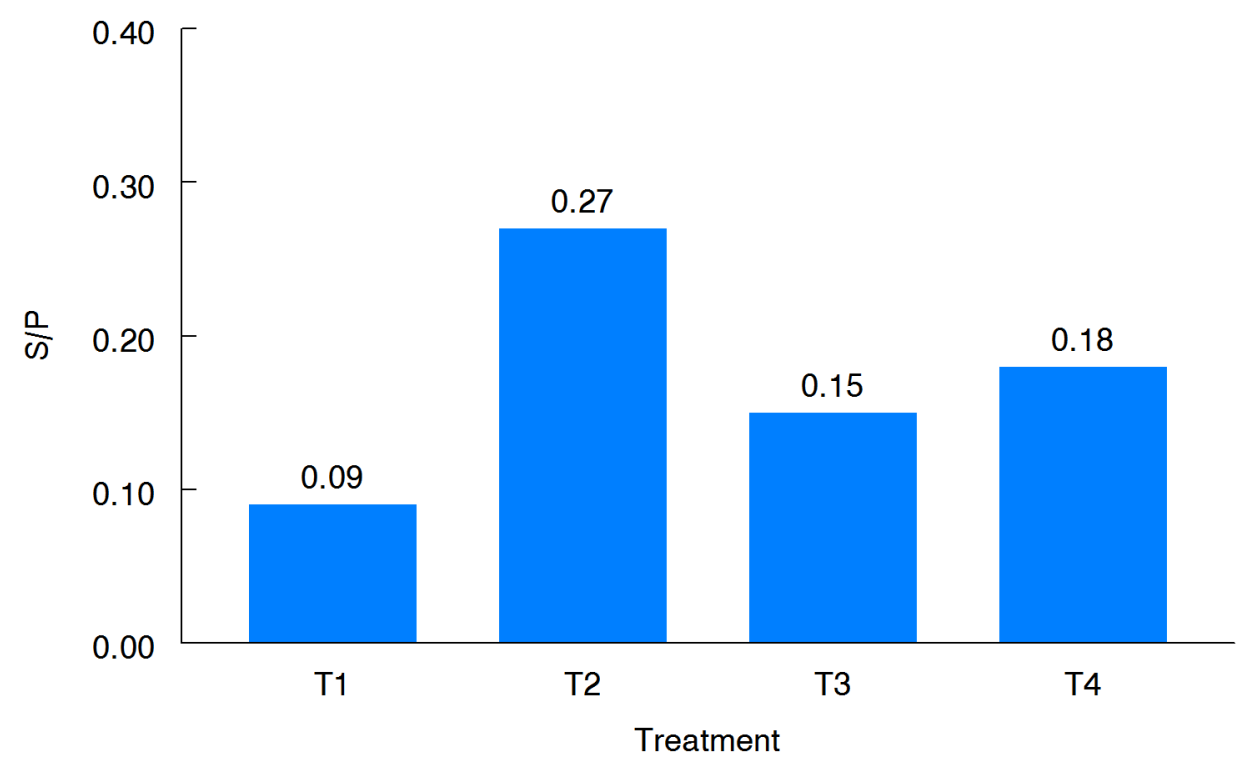

Figure 2 Treatment effects on immunologic response by Isa Brown pullets to infectious bronchitis virus as measured by the optical density ratio S/P

T1: Basal diet without antibiotics, T2: Basal diet with antibiotics, T3: Basal diet with probiotics, and T4: Basal diet without antibiotics and water modified by a photoelectron generator

The treatments had no detectable effect $(P>0.05)$ on the weight and length of most organs of the gastrointestinal tract, or on their relative weights. Only the length of the duodenum was significantly affected by the treatments. Pullets that were given antibiotic had the highest values and those given probiotic had the lowest. The characteristics of the viscera of the pullets during their growing phase are presented in Table 3.

There were no significant differences among treatments $(P>0.05)$ in the histomorphometry of the duodenum (Table 4). This absence may be explained by possible poor colonization of the intestine by the culture in the probiotic, which may also be a reason for its lack of effect on performance measures (Table 2). The villus is the functional unit of the intestine, and there is a high positive correlation between villus size and nutrient absorption rates. Crypt depth is an important indicator of the gastrointestinal tract health. When the intestine is damaged by pathogenic microorganisms, it intensifies cellular turnover in the villus crypt, causing an increase in its depth. This process reduces the villus size to crypt depth ratio (Macari et al., 2002). This may explain the absence of significant differences between treatments for performance parameters, since there was adequate preservation of the intestinal mucosa, regardless of treatment. Therefore, the amount of nutrients needed for enterocyte repair and the rates of nutrient digestion and absorption remained similar.

Bueno et al. (2012) observed a significant $(P<0.05)$ interaction in probiotic treatment and bird age compared with unsupplemented control birds. In Japanese quail, supplementation with probiotics increased crypt depth at 7 days old but reduced it at 35 days old. Abdelqader et al. (2013) provided prebiotics, probiotics and a combination of the two (symbiotics) as supplements for laying hens. Villus height was increased in the duodenum of laying hens that consumed symbiotics, but birds that consumed diets with prebiotics and probiotics showed similar responses. All of the dietary supplements increased villus height relative to the unsupplemented control. Shalaei et al. (2014) also studied the effects of feed additives as replacements for antibiotics on histomorphometry in laying hens. They too observed higher villus height for birds that consumed probiotics. However, the width of the villi was not affected in birds that were supplemented with probiotics or antibiotics compared with those that were fed the control diet. Supplementation with organic acids reduced the width of the villi compared with diets. Shalaei et al. (2014) also found reduced crypt depth and lesser villus/crypt ratios in the duodenum of hens that consumed prebiotics or organic acids compared with the other additives and the control. 
Table 3 Characteristics of viscera $(\mathrm{cm})$ of Isa Brown pullets at 14 weeks old

\begin{tabular}{|c|c|c|c|c|c|c|}
\hline & \multicolumn{4}{|c|}{ Treatments } & \multirow{2}{*}{ General mean } & \multirow{2}{*}{ SE } \\
\hline & $\mathrm{T} 1$ & T2 & T3 & $\mathrm{T} 4$ & & \\
\hline Weight of pancreas, $g$ & 3.3 & 2.8 & 2.9 & 3.3 & 3.1 & 0.13 \\
\hline Pancreas, \% & 0.2 & 0.2 & 0.2 & 0.2 & 0.2 & 0.00 \\
\hline Weight of liver, g & 27.3 & 24.2 & 26.0 & 24.7 & 25.5 & 0.70 \\
\hline Liver, \% & 1.9 & 1.9 & 1.8 & 1.8 & 1.9 & 0.03 \\
\hline Small intestine, $\mathrm{cm}$ & 97.7 & 104.0 & 90.7 & 97.0 & 97.3 & 2.72 \\
\hline Small intestine, g & 32.6 & 29.1 & 30.7 & 31.3 & 30.9 & 0.73 \\
\hline Small intestine, \% & 2.3 & 1.9 & 2.2 & 2.3 & 2.2 & 0.09 \\
\hline Duodenum, $\mathrm{cm}$ & $17.8^{\mathrm{ab}}$ & $19.3^{\mathrm{a}}$ & $16.5^{\mathrm{b}}$ & $18.0^{\mathrm{ab}}$ & 17.9 & 0.57 \\
\hline Duodenum, g & 8.2 & 7.9 & 6.8 & 7.5 & 7.6 & 0.30 \\
\hline Duodenum, \% & 0.6 & 0.6 & 0.5 & 0.5 & 0.6 & 0.03 \\
\hline Jejunum, cm & 41.3 & 45.3 & 42.0 & 43.0 & 42.9 & 0.87 \\
\hline Jejunum, g & 14.4 & 12.4 & 13.8 & 13.1 & 13.4 & 0.43 \\
\hline Jejunum, \% & 1.01 & 0.96 & 0.97 & 0.97 & 0.98 & 0.01 \\
\hline Ileum, cm & 38.5 & 39.3 & 32.2 & 36.0 & 36.5 & 1.60 \\
\hline Ileum, g & 10.0 & 8.8 & 10.0 & 10.6 & 9.9 & 0.38 \\
\hline Ileum, \% & 0.7 & 0.7 & 0.7 & 0.8 & 0.7 & 0.03 \\
\hline Large intestine, $\mathrm{cm}$ & 8.3 & 9.2 & 8.3 & 8.2 & 8.5 & 0.23 \\
\hline Large intestine, g & 3.9 & 4.7 & 3.7 & 3.2 & 3.9 & 0.31 \\
\hline Large intestine, \% & 0.3 & 0.4 & 0.3 & 0.2 & 0.3 & 0.04 \\
\hline Cecum, cm & 12.8 & 11.7 & 11.5 & 12.0 & 12.0 & 0.29 \\
\hline
\end{tabular}

T1: Basal diet without antibiotics, T2: Basal diet with antibiotics, T3: Basal diet with probiotics, and T4: Basal diet without antibiotics and water modified by a photoelectron generator

Table 4 Duodenal histomorphometry of Isa Brown pullets receiving diets with functional additives to replace antibiotics from 7 to 14 weeks old

\begin{tabular}{|c|c|c|c|c|c|}
\hline \multirow[b]{2}{*}{ Histomorphometry } & \multicolumn{4}{|c|}{ Treatments } & \multirow{2}{*}{ SE } \\
\hline & $\mathrm{T} 1$ & T2 & T3 & T4 & \\
\hline Villus height & 711.2 & 684.4 & 729.0 & 728.0 & 10.42 \\
\hline Villus width & 83.6 & 87.9 & 79.2 & 102.0 & 4.94 \\
\hline Crypt depth & 31.8 & 38.8 & 34.9 & 33.5 & 1.49 \\
\hline Crypt height/depth & 22.3 & 18.8 & 20.9 & 21.9 & 0.78 \\
\hline Villus heightlwidth & 0.12 & 0.13 & 0.11 & 0.15 & 0.01 \\
\hline
\end{tabular}

T1: Basal diet without antibiotics, T2: Basal diet with antibiotics, T3: Basal diet with probiotics, and T4: Basal diet without antibiotics and water modified by a photoelectron generator

The intestinal microbiota is sensitive and dynamic. Thus, environmental conditions, nutritional status and health challenges influence its composition and the interrelationship among the microorganisms. Studies of dietary manipulations of the intestinal microbiota have produced contrasting results in laying hens and broilers. The microbial challenge in experimental facilities may be low compared with that in commercial poultry buildings. Typically, experimental sheds have longer sanitary breaks between batches of birds and better hygiene than commercial facilities. These differences result in less microbial contamination in experimental facilities than in commercial poultry houses. In studies of alternatives to antibiotics, contrasting 
results are often observed because of differences in the products and in the methodologies (Reis \& Vieites, 2019). In the present study the absence of significant differences among treatments shows that the sanitary challenge was low. Perhaps disproportionate colonization of the gastrointestinal tract by the beneficial microbiota did not occur when the additives were supplied or when the water was modified.

The feed in this study was not contaminated with microorganisms because no colonies formed in 24 hours incubation on PDA (Figure 3). This feed had been kept frozen from the time it was prepared until this assay was conducted. Likewise, samples from the litter in boxes of birds fed T2 generated no microbial colonies. These samples would have almost certainly have produced colonies of microbes if incubated longer. However, litter from the boxes of the T1, T3 and T4 produced $2.3 \times 10^{7}, 2.9 \times 10^{6}$ and $1.9 \times 10^{8}$ CFUs, respectively. The 24-hour incubation time was chosen to count the CFUs to show the potential bactericidal and bacteriostatic characteristics of T2 (Pedroso et al., 2005).

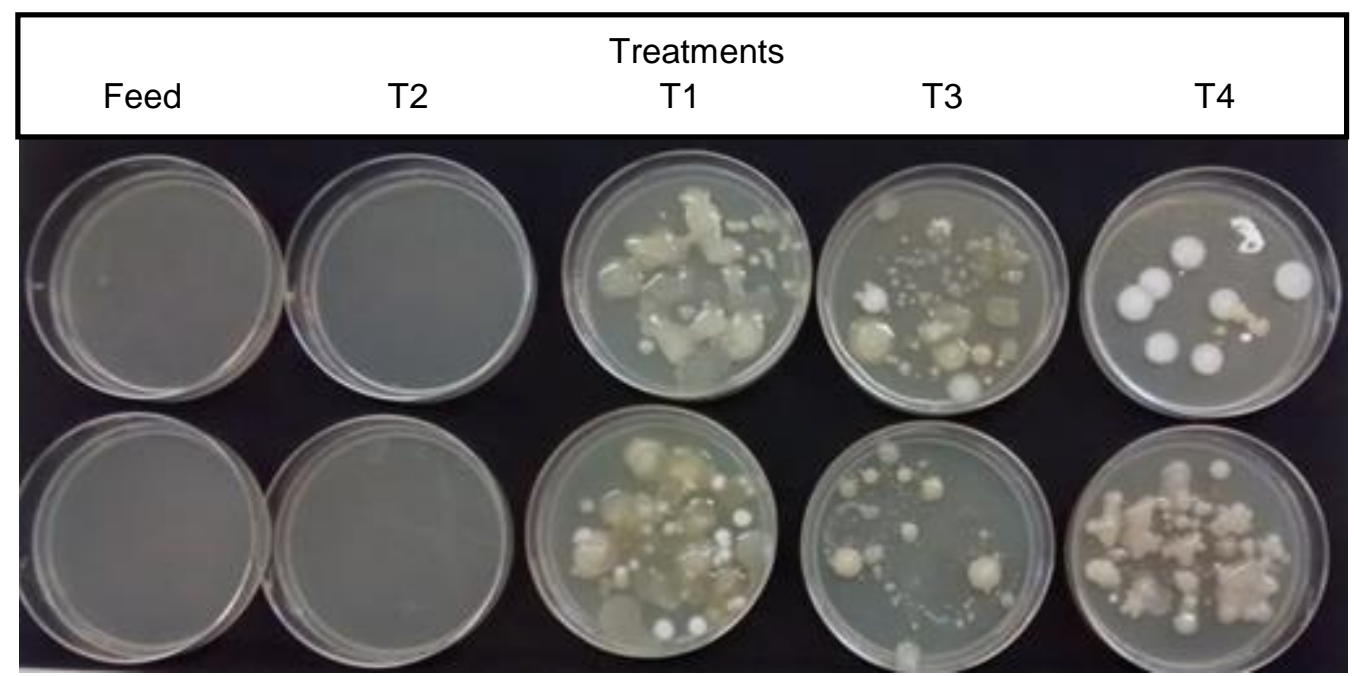

Figure 3 Visualization of treatment differences in microbial colonies grown on bacteriological agar substrate from samples of feed and litter

T1: Basal diet without antibiotics, T2: Basal diet with antibiotics, T3: Basal diet with probiotics, and T4: Basal diet without antibiotics and water modified by a photoelectron generator

The lack of microbial growth seeded by litter from T2 suggests that residual effects prevented microbial proliferation. However, the litter from T1, T3 and T4 showed significant microorganism development, which suggested that these alternatives were natural and non-bactericidal. In contrast to the results observed for T3, Brustolin et al. (2014) previously suggested that feeding probiotics to poultry might help in controlling bacterial contamination in litter. It is thus speculated that the litter from T1, T3, and T4 would decompose in less time than litter from T2 and would cause less environmental impact. Many factors can influence bacterial viability and multiplication in the litter of an aviary. These include water activity, $\mathrm{pH}$, temperature, humidity and the presence of ammonia, which may vary between methods of litter management and treatment (Silva, 2006).

Hassanein and Soliman (2010) found a higher count of Lactobacillo sp. in the digestive tracts of laying hens that were supplemented with probiotics. These hens also had reduced concentrations of Escherichia coli, Klebsiella sp., Staphylococcus sp., Micrococcus sp., Campylobacter sp. and Closterdium in the ileum. Abdelqader et al. (2013) found higher concentrations of Lactobacillus and Bifidobacterium in the ileum and cecum of laying hens that had been fed probiotic, prebiotic, and symbiotic compared with an unsupplemented control. The Clostridium sp. concentration was also reduced in these organs of hens that were subjected to these treatments. Mountzouris et al. (2010) observed that including probiotics in diets for broiler chickens promoted beneficial modulation of the cecal microbiota composition at 42 days old, but not at 14 and 28 days old. 


\section{Conclusion}

The use of dietary alternatives to antibiotics was viable for semi-heavy laying hens during the growing phase under the conditions of this study. However, even the unsupplemented T1 birds had a similar performance to those birds whose diet was supplemented with an antibiotic. The T2 treatment hindered the development of microorganisms in litter samples. On the other hand, the use of T3 and T4 promoted microbiological development in litter samples, which suggested potential for its more rapid decomposition and reduction of environmental impact. Because these augmentations are innovative, natural, and non-toxic, and do not induce bacterial resistance, they may be alternatives to antibiotics. More research is needed to determine their beneficial effects.

\section{Acknowledgements}

The authors thank the Animal Science Institute for the opportunity given to the first author to pursue a master's degree. Hendrix Genetics Ltda - Brasil is acknowledged for providing one-day-old chicks of the Isa Brown strain. The authors thank Sérgio Kenji Kakimoto of Granja Kakimoto for logistic and operational support, and TAMURA Co., Ltd., and in particular Mr. Paulo Tatsuo Matuda, for making the Dileka equipment available for the experiment.

\section{Authors' Contributions}

SMCT, JEM, FELB, CCP were responsible for the animal management, data collection and laboratory analyses. CCP was also responsible for the statistical analysis and writing of the scientific paper. DFS participated in animal management. NYS assisted in the slaughter of the birds. KMRD performed the microbiological analyses. SKK donated the diet ingredients, borrowed the Dileka equipment, and performed the blood collection. TLR wrote the scientific paper. LA did the histomorphometric analyses.

\section{Conflict of Interest Declaration}

The authors declare that there was no conflict of interest.

\section{References}

Abdelqader, A., Al-Fataftah, A.R. \& Daş, G., 2013. Effects of dietary Bacillus subtilis and inulin supplementation on performance, eggshell quality, intestinal morphology and microflora composition of laying hens in the late phase of production. Anim. Feed Sci. Technol. 179(4), 103-111. DOI: 10.1016/j.anifeedsci.2012.11.003

Ajuwon, K. M., 2015. Toward a better understanding of mechanisms of probiotics and prebiotics action in poultry species. J. Appl. Poult. Res. 25(2), 277- 283. DOI: 10.3382/japr/pfv074

Albuquerque, R., 2005. Antimicrobianos como promotores de crescimento. In: J. Palermo Neto, H.S. Spinosa \& S.L. Górniak (editors). Farmacologia aplicada à avicultura. 1st ed. Editora Roca. São Paulo. Pp.149-159. (In Portuguese).

Al-Shammari, K.I., Batkowska, J. \& Gryzińska, M.M., 2017. Effect of various concentrations of an anise seed powder (Pimpinella Anisum L.) supplement on selected hematological and biochemical parameters of broiler chickens. Braz. J. Poult. Sci. 19(1), 41-46. https://www.scielo.br/scielo.php?script=sci_arttext\&pid=S1516635X2017000100041

APHA (American Public Health Association)., 2001. Compendium of methods for microbiological examination of foods. 4th edition. American Public Health Association, Washington, DC.

Bai, S.P., Wu, A.M., Ding, X.M., Lei, Y., Bai, J., Zhang, K.Y. \& Chio, J. S., 2013. Effects of probiotic-supplemented diets on growth performance and intestinal immune characteristics of broiler chickens. Poult. Sci. 92(3), 663-670. DOI: $10.3382 /$ ps.2012-02813

Bastos-Leite, S.C., Alves, E.H.A., Sousa, A.M.D., Goulart, C.D.C., Santos, J.P.M.D. \& Silva, J.D.B., 2016. Ácidos orgânicos e óleos essenciais sobre o desempenho, biometria de órgãos digestivos e reprodutivos de frangas de reposição. Acta Vet. bras. 10(3), 201-207. (In Portuguese, English abstract).

Belal, S.A., Uddin, M.N., Hasan, M.K., Islam, M.S. \& Islam, M.A., 2018. Effect of ginger (Zingiber officinale) and garlic (Allium sativum) on productive performance and hematological parameters of the broiler. Int. J. Environ. Res. 4, 12-23.

Borsoi, A. \& Palermo Neto, J. 2015. Uso de antimicrobianos na postura comercial. Problema e saúde aviária ou de saúde pública? In: XIII Congresso APA de produção e comercialização de ovos. Ribeirão Preto, São Paulo. pp. 1-7 (In Portuguese).

Brenes, A. \& Roura, E., 2010. Essential oils in poultry nutrition: Main effects and modes of action. Anim. Feed Sci. Technol. 158(1-2), 1-14. DOI: 10.1016/j.anifeedsci.2010.03.007

Broom, D.M. \& Johnson, K.G., 1993. Stress and animal welfare. Animal Behaviour Series. Chapman \& Hall, London.

Brustolin, J., Lovato, M., Weiller, M.A.A., Tavares, T.M., Gianluppi, R.D. \& Ferronato, P.H., 2014. Effect of the use of a Bacillus subtilis and Bacillus cereus based probiotic on chicken litters challenged with Salmonella Enteritidis. In: International Poultry Scientific Forum World Congress Center. Atlanta, Georgia. pp. 56-56.

Bueno, R., Albuquerque, R., Murarolli, V.D.A., Aya, L.A.H., da Silva Raposo, R. \& de Andrade Bordin, R., 2012. Efeito da influência de probiótico sobre a morfologia intestinal de codornas japonesas. Braz. J. Vet. Res. Anim. Sci. 49(2), 111-115. (In Portuguese, English abstract).

CONCEA (Conselho Nacional de Controle de Experimentação Animal)., 2013. Diretrizes da Prática de Eutanásia do Concea. Ministério da Ciência, Tecnologia e Inovação. Brasília, Distrito Federal, 54 pp. (In Portuguese). 
Corcionivoschi, N., Drinceanu, D., Pop, I.M., STACK, D., Ştef, L., Julean, C. \& Bourke, B., 2010. The effect of probiotics on animal health. Scient Pap Anim Sci Biotech. 43(1), 35-41.

Dileka - Água natural que suas aves precisam. $\quad$ Dileka, São Paulo 2019.https://jornalevolucao.jimdo.com/not\%C3\%ADcias/dileka/. (In Portuguese).

Ferreira, D.F., 2011. Sisvar: a computer statistical analysis system. Ciência e Agrotecnologia 35(6), 1039-1042. https://doi.org/10.1590/S1413-70542011000600001

Fonseca, F.C.P. \& Costa, C.L., 2010. Influência da nutrição sobre o sistema imune intestinal. Rev. Ceres. 5(3), $163-174$. (In Portuguese, English abstract).

Fukayama, E.H., Bertechini, A.G., Geraldo, A., Kato, R.K. \& Murgas, L.D.S., 2005. Extrato de orégano como aditivo em rações de frangos de corte. Rev. Bras. Zootec. 34, 2316-2326. (In Portuguese).

Fuller, R., 1989. Probiotics in man and animals. J. Appl. Bacteriol. 66 (5), 365-378.

Gadde, U., Kim, W.H., Oh, S.T. \& Lillehoj, H.S. 2017. Alternatives to antibiotics for maximizing growth performance and feed efficiency in poultry: A review. Anim. Health Res. Rev. 18(1), 26-45. DOI: 10.1017/S1466252316000207.

Gava, M.S., Moraes, L.B.DE, Carvalho, D., Chitolina, G.Z., Fallavena, L.C.B., Moraes, H.L.S., Herpich, J.I. \& Salle, C.T.P., 2015. Determining the best sectioning method and intestinal segment for morphometric analysis in broilers. Rev. Bras. Cienc. Avic. 17, 145-150. DOI: 10.1590/1516-635x1702145-150.

Hassanein, S. M. \& Soliman, N. K., 2010. Effect of probiotic (Saccharomyces cerevisiae) adding to diets on intestinal microflora and performance of Hy-Line layers hens. J. Am. Sci. 6(11), 159-169.

Havenaar, R.; Brink, B.T. \& Huis-int'veld, J.H.J., 1992. Selection of strains for probiotic use. In: Chapman \& Hall. London, UK. DOI: 10.1007/978-94-011-2364-8_9.

Hinton, A.J.R., Buhr, R.J. \& Ingram, K.D., 2000. Reduction of Salmonella in the crop of broiler chickens subjected to feed withdrawal. Poultr. Sci. 79,1566-1570. DOI: 10.1093/ps/79.11.1566

ISA, 2015. Commercial product guide Isa Brown North American version. Netherlands, EU. Pp. 72.

Leedle, J. 2000. Probiotics and DFMs-mode of action in the gastrointestinal tract., In: Simpósio Sobre Aditivos Alternativos Na Nutrição Animal. Colégio Brasileiro de Nutrição Animal. Campinas, São Paulo. pp. 25-40.

Lemos, M.J.D., Calixto, L.F.L., Torres-Cordido, K.A.A. \& Reis, T.L., 2016. Uso de aditivo alimentar equilibrador da flora intestinal em aves de corte e de postura. Arq. Inst. Biol. 83, 1-7. DOI: 10.1590/1808-1657000862014.

Macari, M., Furlan, R.L. \& Gonzales, E., 2002. Fisiologia aviária aplicada a frangos de corte. 2nd edition Editora FUNEP/UNESP. Jaboticabal, Brazil. (In Portuguese).

Mashayekhi, H., Mazhari, M. \& Esmaeilipour, O., 2018. Eucalyptus leaves powder, antibiotic and probiotic addition to broiler diets: Effect on growth performance, immune response, blood components and carcass traits. Anim. 12, 2049-2055. DOI: 10.1017/S1751731117003731.

Menten, J.F.M., 2001. Aditivos alternativos na produção de aves: probióticos e prebióticos. In: Reunião anual da sociedade brasileira de zootecnia. Piracicaba, São Paulo. p.141-157. (In Portuguese, English abstract).

Mountzouris, K. C., Tsitrsikos, P., Palamidi, I., Arvaniti, A., Mohnl, M., Schatzmayr, G. \& Fegeros, K., 2010. Effects of probiotic inclusion levels in broiler nutrition on growth performance, nutrient digestibility, plasma immunoglobulins, and cecal microflora composition. Poultr. Sci. 89(1), 58-67. DOI: 10.3382/ps.2009-00308.

NRC (National Research Council), 2004. Research priorities for airborne particulate matter: IV. Continuing research progress. Vol. 4. National Academies Press, Washington, DC.

Oliveira-Sequeira, T.C.G.D., Ribeiro, C.M. \& Gomes, M.I.F.V., 2008. Potencial bioterapêutico dos probióticos nas parasitoses intestinais. Cienc. Rural. 38 (9), 2670-2679. DOI: 10.1590/S0103-84782008005000001. (In Portuguese, English abstract).

Otutumi, L.K., Furlan, A.C., Natali, M.R.M., Martins, E.N.M., Loddi, M.M. \& Oliveira, A.F.G., 2008. Utilização de probiótico em rações com diferentes níveis de proteína sobre o comprimento e a morfometria do intestino delgado de codornas de corte. Acta Scientiarum Animal Sciences $30(3), \quad 283-289 . \quad$ DOI: 10.4025/actascianimsci.v30i3.804. (In Portuguese, English abstract).

Paz, A.S.D., Abreu, R.D., Costa, M.D.C.M.M.D., Jaeger, S.M.P.L., Rocha, A.P., Ferreira, B.P., Santana, R.S. \& Campos, B.M., 2010. Aditivos promotores de crescimento na alimentação de frangos de corte. Rev. Bras. Saúde Prod. Anim. 11, 395-402. (In Portuguese, English abstract).

Pedroso, A.F , Nussio, L.G., Paziani, S.F., Loures, D.R.S., Igarasi, M.S., Coelho, R.M., Packer, I.H. \& Gomes, .H., 2005. Fermentation and epiphytic microflora dynamics in sugar cane silage. Scientia Agrícola (USP. Impresso), Piracicaba, 62(5), 427-432.

Prestes, E.B., 2007. Avaliação da eficiência do ozônio como sanitizante em hortaliças folhosas minimamente processadas. Thesis. Campinas, São Paulo. Universidade Estadual de Campinas (UNICAMP) pp.135f. (In Portuguese, English abstract).

Reis, T.L. \& Vieites, F.M., 2019. Antibiótico, prebiótico, probiótico e simbiótico em rações de frangos de corte e galinhas poedeiras. Cienc. Anim. 29 (3), 133-147. (In Portuguese, English abstract).

Rostagno, H.S., Albino, L.F.T., Donzele, J.L., Gomes, P.C., Oliveira, R.F., Lopes, D.C., Ferreira, A.S., Barreto, S.L.T. \& Euclides, R.F., 2011. Tabelas brasileiras para aves e suínos: composição de alimentos e exigências nutricionais. 3rd ed. UFV, Departamento de Zootecnia. Viçosa, MG, Brasil. pp. 252.

Shalaei, M., Hosseini, S.M. \& Zergani, E., 2014. Effect of different supplements on eggshell quality, some characteristics of gastrointestinal tract and performance of laying hens. Vet Res Forum. 5 (4), 277-286.

Silva, A.L., 2006. Utilização de Cama de Frango e Diferentes Níveis de adubação Nitrogenada para Obtenção de Matéria Seca em Brachiaria cv. Arandu. Faculdades Integradas de Mineiros. Monograph Graduation. Mineiros, Goiás. Faculdades Integradas de Mineiros. pp. 45. (In Portuguese, English abstract). 
Singh, B.K. \& Walker, A., 2006. Microbial degradation of organophosphorus compounds. FEMS Microbiol. Rev., 30(3), 428-471. DOI: 10.1111/j.1574-6976.2006.00018.x

Smith, A.L. \& Beal, R. 2008. The avian enteric immune system in health and disease. In: F. Davison, B. Kaspers \& K.A Schat. Avian immunology. Elsevier, London, pp. 243-271.

Soares, L.L.P. 1996. Restrições e uso de aditivos (promotores de crescimento) em ração de aves. Visão do fabricante. In: Conferência Apinco de Ciência e Tecnologia Avícola. Curitiba, Paraná. p.27-36, 1996. (In Portuguese, English abstract).

Tolosa, E.M.C., Rodrigues, C.J., Behmer, O.A. \& Freitas-Neto, A.G., 2003. Manual de técnicas para histologia normal e patológica. 2nd ed. São Paulo. 331.

Vijayasteltar, L., Nair, G.G., Maliakel, B., Kuttan, R. \& Krishnakumar, I.M., 2016. Safety assessment of a standardized polyphenolic extract of clove buds: Subchronic toxicity and mutagenicity studies. Toxicol. Repor. 3, 439-449. DOI: 10.1016/j.toxrep.2016.04.001.

Youssef, A. W., Hassan, H.M.A., Ali, H.M. \& Mohamed, M.A., 2013. Effect of probiotics, prebiotics and organic acids on layer performance and egg quality. Asian J. Poult. Sci. 7(2), 65-74. DOI: 10.3923/ajpsaj.2013.

Zhang, J.L., Xie, Q.M., Ji, J., Yang, W.H., Wu, Y.B., Li, C. \& Bi, Y.Z., 2012. Different combinations of probiotics improve the production performance, egg quality, and immune response of layer hens. Poultr. Sci. 91(11), 2755-2760. DOI: $10.3382 /$ ps.2012-02339. 